\title{
Citizen Participation and Transparency in Local Government: Do Participation Channels and Policy Making Phases Matter?
}

\author{
Soonhee Kim \\ KDI School of Public Policy and \\ Management \\ soonheekim@kdischool.ac.kr
}

\author{
Jooho Lee \\ School of Public Administration \\ University of Nebraska at Omaha \\ jooholee@unomaha.edu
}

\begin{abstract}
The purpose of this study was to analyze the relationship between citizen engagement in various public participation programs and the participants' assessment of transparency in local government. To examine this relationship, the study focused on three aspects of citizen participation: (1) citizen engagement in participation programs generally, (2) online versus offline participation, and (3) online or offline participation in policymaking phases specifically. A 2009 survey of residents of Seoul, South Korea, was used to test the study hypotheses, as it provided information from 1,014 respondents on their citizen participation and their perceptions of transparency in government. Surprisingly, citizens' engagement in public participation programs was not significantly associated with perceptions of transparency in government. Moreover, citizen participation in online programs had a marginally negative association with assessments of government transparency. However, citizens who engaged in offline participation programs during the policy agenda setting phase indicated a more favorable assessment of transparency in local government.
\end{abstract}

\section{Introduction}

Citizen participation research has progressed significantly over the last two decades $[12,37$, 41, 43, 44, 51]. Researchers and practitioners have emphasized citizen participation in public administration as a means of collaborating with citizens to promote democratic values such as transparency and accountability $[12,14,16,23$, 27, 44, 48]. Cooper et al [12] further argue that deliberative and collective action strategies of civic engagement are the most promising ways to involve the public and focus public management on citizen concerns. Several scholars also emphasize that providing more opportunities for citizen participation and input in government performance evaluation and policy decision making is an important strategy for improving trust in government [10, 20, 25].

A growing body of literature describes government efforts to harness new technologies in order to enable greater citizen participation in policy formation and evaluation and create more robust information exchange between citizens and government [26, 28, 32,]. Many governments have adopted various forms of electronic participation (e-participation) applications, including online forums, virtual discussion rooms, electronic juries, and electronic polls [32].

Significant gaps remain, however, in our understanding of how to measure the outcomes of citizen participation programs, and limited attention has been paid to the evaluation of such programs at the local government level. Local governments continuously face the challenge of improving their quality of public service and their ability to implement adequate policies and practices in response to economic and social development needs. Development demands also influence citizens' expectations regarding local government responsiveness, transparency, and accountability. Citizens and community organizations frequently express their desire for a more participatory approach to decisionmaking processes, as well as for greater transparency and accountability from their local government [15].

Scholars and practitioners alike view transparency as an essential democratic value that undergirds a trustworthy, high-performing, and accountable government [46]. Kim [19] argues that local governments can enhance their level of transparency through a commitment to three core components of transparency: openness, integrity, and citizen empowerment. A high degree of openness among public officials and agencies regarding all the decisions and actions that they take can reduce the information gaps between government and citizens and enhance the level of transparency. Some other 
components of openness could include good information and knowledge sharing between sectors and across agencies, along with the use of multiple methods to communicating government activity and functions to the local community. Kim [19] further contends that integrity, or incorruptibility, is another crucial dimension of transparency. Integrity requires holders of public office to avoid placing themselves under financial or other obligations to outside individuals or organizations who may influence them in the performance of their official duties [9, 35]. Finally, citizens' perceived empowerment through fair and increased opportunities to participate in the decisionmaking processes of local government could be another indicator of the government's degree of transparency [19].

The purposes of the present study are twofold. First, it attempts to empirically examine the relationship between citizens' engagement in participation programs and their assessment of government transparency. Second, it investigates how citizens' engagement via offline and online participation programs at different phases of policy making processes is related to their assessment of transparency in government. To measure citizens' assessment of transparency in local government, the study focuses on their perceptions of openness, corruption, two-way communication with citizens, and fair and increased opportunities to participate in the local government's policy making process [19]. To test its proposed hypotheses, the study uses 2009 Citizen Survey data collected from 1,014 residents of Seoul, South Korea.

\section{Literature Review and Hypotheses}

The emerging literature on collaborative governance in public administration has emphasized that citizens should be considered as collaborative partners in an effort to build effective democratic governance [29, 30]. Among the various definitions of citizen participation, this paper adopts that of Verba et al [47], who described it as any voluntary action by citizens that is more or less directly aimed at influencing the management of collective affairs and public decision making. The evolution of citizen participation in public administration decision making has recently entered a new phase as many government agencies have initiated e-government activities and have taken advantage of Internet-based applications to communicate with constituents and to provide online application services.

Scholars have categorized several types of citizen participation programs. For instance, Arnstein [1] introduces a ladder of participation that describes levels of interaction and influence in the decision-making process, moving from basic to more in-depth participation: information, communication, consultation, deliberation, and actual decision making. Rowe and Frewer [40] similarly categorize three different levels of citizen participation: (1) communication, where information is conveyed from the government body to the public; (2) consultation, where information flows from the public to the government; and (3) participation, where information is exchanged between the public and the government and some degree of dialogue takes place. Lastly, public administration literature has characterized citizen participation as one part of policy decision-making processes, which include agenda setting, policy formation, implementation, and evaluation phases $[1,23]$.

Evaluating the performance of various citizen participation programs in collaborative governance is a complex matter. Governments may face difficulties in designing customized performance evaluation methods suitable for the various types, formats, and purposes of online and offline participation programs at policy making phases. One of the core values or goals of citizen participation programs and policies is usually to enhance perceptions of government transparency, including openness in governmentrelated application processes and decision making. This study explores how citizens' engagement in participation programs and their experiences of online participation and offline participation in different phases of policy making processes are associated with their assessment of the transparency of the local government providing these participation programs.

\subsection{Citizen Participation and Transparency}

According to scholars in the field of citizen participation, citizens who receive quality feedback and responsiveness when interacting with government through public participation programs are likely to perceive that they gain useful policy information that helps them to better understand government agencies and community issues $[4,42,53]$.

This study predicts that citizens' engagement in public participation programs should be positively associated with their 
assessment of government transparency. The participants in such programs should learn more about community issues than other citizens who do not engage in them. Those citizens who are engaged in the participation programs may perceive that government agencies are capable of providing transparency, two-way communication with citizens, and participatory governance.

Hypothesis 1: citizens' engagement in both online and offline participation programs will be positively associated with their assessment of transparency in local government.

\subsection{Online and Offline Participation and Transparency}

Scholars report that using Internet-based interactive technology to facilitate citizen participation programs not only helps to gauge citizen preferences in government decisions, but also improves decision making and transparency $[2,34,38,45]$. Compared to offline participation programs, online participation programs allow a more efficient distribution of government policy and programs to citizens $[5,17]$ and a higher level of interactive communication between government employees and citizens as well as among citizens [34].

Scholars have also found that the ease and effectiveness of online participation applications motivates citizens to use them [5, 22, 33]. Online participation programs often allow citizens to locate public policy and program information on community issues (e.g., policy proposals or progress reports) more readily. Also, they give citizens greater ability to offer input or ask questions on policy and community issues, to view other participants' ideas, and to share their thoughts with others $[11,50]$. Furthermore, online participation programs increase flexibility, as citizens can visit websites at their convenience, view ongoing forum discussions repeatedly, and post their own ideas whenever they wish [38].

Online participation programs have become a useful tool in expanding the scope and breadth of information available to the general public and to key constituents [34, 38]. For example, the City of Virginia Beach makes its financial information available online to encourage stakeholder participation, increase awareness, and demonstrate financial accountability [34]. Real-time, interactive, web-based methods also enable citizens to engage in complex technical issues such as tax and budget choices [38].

Hypothesis 2: Citizens who engage in online participation programs are more likely to indicate a more favorable assessment of transparency in local government than those citizens who engage in offline participation programs.

\subsection{Online and Offline Citizen Participation in Policymaking Phases and Transparency}

One criticism of citizen participation practices is that participation often takes place only after the policy agenda has been set and decisions have been made [23]. In this regard, citizen participation in the agenda setting stage is important because it reflects one of the key components of authentic participation, namely that it should be sought in early stages of the decision-making process, before any decisions are finalized [23].

One distinctive characteristics of citizen participation programs at the policy agenda setting phase (e.g. open policy forum) is that they are often broadly open to the public. However, citizen participation programs for policy formulation, decision making, implementation, and evaluation are narrowly open to the public. Thus, citizens, in general, are relatively limited to access to information about a policy and observe how policy is formulated, implemented, and evaluated.

When citizen participation programs are open to the public, public participants are given opportunities to gain easier access to relevant information about potential policy agenda and observe how public administrators, policy makers, and peer participants express, exchange, frame, and shape their opinions and preferences. Moreover, thanks to advanced technologies, citizens' participation in agenda setting phases become more prominent. Online participation programs for policy agenda setting (e.g. online policy forum) broaden the range of participation by lowering physical and psychological barriers for more citizens to gain easier access to public issues, provide input, and observe how those issues and citizens input are framed and shaped.

Hypothesis 3: Citizens' engagement in participation programs during the policy agenda setting phase is positively correlated with their assessment of transparency in local government

Hypothesis 4: Citizens' engagement in online participation programs during the policy agenda setting phase is positively related to their assessment of transparency in local government

\section{Research Methods \\ 3.1. Data collection}


To test the research hypotheses, we used 2009 Citizen Survey data collected from residents in Seoul. The 2009 Citizen Survey was originally designed to understand attitudes toward various citizen behaviors, including perceptions of citizen participation program experience, volunteer experience, and civic engagement. The survey was conducted in June 2009, using face-to-face interviews at six sites, including places around four Seoul Metropolitan Government (SMG) offices. We collected 1,014 usable surveys. Table 1 depicts the sample distribution with regard to gender and age.

Table 1. Demographics

\begin{tabular}{cccc}
\hline Variable & Characteristics & $\begin{array}{c}\text { Respondents } \\
(\%)\end{array}$ & $\begin{array}{c}\text { Population } \\
(\%)\end{array}$ \\
\hline \multirow{2}{*}{ Gender } & Male & 43.6 & 50.1 \\
& Female & 56.4 & 49.9 \\
\hline \multirow{6}{*}{ Age } & Twenties or & 21.9 & 18.8 \\
& less & & 18.3 \\
& Thirties & 27.4 & 16.7 \\
& Forties & 31.0 & 11.9 \\
& Fifties & 14.5 & 10.3 \\
\hline
\end{tabular}

Note: The population of city of Seoul was $10,464,051$

as of December 31, 2009, according to the 2010

National Population and Housing Census Survey of South Korea (www.seoul.go.kr).

\subsection{Measurement}

Perceived transparency in government. The dependent variable of perceived transparency in government was measured using two survey items. The participants were asked to evaluate SMG efforts to improve transparency in civil application procedures and in decision-making processes, using a 5-point Likert-type scale ranging from "strongly disagree" (1) to "strongly agree" (5). (See the Appendix for the survey items.)

Citizen participation. The first main independent variable, citizen engagement in participation programs, was measured in terms of respondents' actual participation in such programs within SMG. In the survey questionnaire, we provided a list of $23 \mathrm{SMG}$ participation programs, 14 of them offline (e.g., public hearings) and 9 online (e.g., online policy forums). Respondents were asked to check all types of citizen participation programs that they had actually used during the last 12 months. We coded answers as 1 if respondents indicated having participated in any program (either offline or online) or 0 if they did not indicate any programs. Overall, $12.6 \%$ of respondents indicated having used at least one SMG participation program.

Citizens' online participation. We also differentiated survey respondents' engagement between SMG's online and offline participation programs. We coded this variable as 1 if a respondent indicated having participated in any online program or 0 if not. Overall, $9.7 \%$ of respondents reported that they had used at least one offline citizen participation program, whereas $6.7 \%$ had used at least one eparticipation program.

Citizens' participation in policymaking phases. As shown in Table 2, we measured citizens' participation in policymaking phases using two dimensions: three stages of the policymaking process (i.e., agenda setting, implementation, and evaluation) and two participation channels (i.e., offline and online).

Table 2 Participation Programs

\begin{tabular}{|c|c|c|}
\hline & Offline (14) & Online (9) \\
\hline $\begin{array}{c}\text { Policy } \\
\text { agenda setting }\end{array}$ & $\begin{array}{l}\text { Town hall } \\
\text { meetings } \\
\text { Open policy } \\
\text { discussion } \\
\text { forums of four } \\
\text { different city } \\
\text { projects, } \\
\text { programs, and } \\
\text { policies (e.g, } \\
\text { consolidation of } \\
\text { administrative } \\
\text { offices) }\end{array}$ & $\begin{array}{l}\text { Suggestions } \\
\text { through Oasis } \\
\text { Ask the Mayor } \\
\text { Ideas about } \\
\text { reducing city } \\
\text { costs } \\
\text { Citizen input } \\
\text { for public } \\
\text { notice } \\
\text { Online policy } \\
\text { discussion } \\
\text { forum } \\
\text { Cyber policy } \\
\text { discussion } \\
\text { forum }\end{array}$ \\
\hline $\begin{array}{c}\text { Policy } \\
\text { implementation }\end{array}$ & $\begin{array}{l}\text { Volunteer } \\
\text { programs run by } \\
\text { SMG } \\
\text { Cultural events } \\
\text { organized by } \\
\text { SMG (e.g., Hi- } \\
\text { Seoul Festival) }\end{array}$ & $\mathrm{N} / \mathrm{A}$ \\
\hline $\begin{array}{c}\text { Policy } \\
\text { evaluation }\end{array}$ & $\begin{array}{l}\text { Citizen monitor } \\
\text { Citizen } \\
\text { ombudsman } \\
\text { Mystery shopper } \\
\text { Policy Evaluation }\end{array}$ & $\begin{array}{l}\text { Civil application } \\
\text { process (open } \\
\text { systems) } \\
\text { Online request } \\
\text { for government }\end{array}$ \\
\hline
\end{tabular}




$\begin{array}{ll}\text { Committee } & \text { information } \\ \text { General citizen } & \text { Open budget } \\ \text { survey } & \\ \text { Citizen } & \\ \text { satisfaction } & \\ \text { survey } & \\ \text { Honorary } & \\ \text { overseer } & \end{array}$

Control variables. Scholars indicate that government efforts to provide more and fairer opportunities for citizen participation and input in government performance evaluation and policy decision making can be an important strategy for improving transparency, and trust in government $[21,25]$. To account for this finding, we included perception of government's effort to engage citizens as a control variable. It was measured using three survey items: promotion of two-way communications, increased opportunities for diverse citizen participation, and improved fairness in citizen participation. The summative index of the three questions was used in the analysis (Cronbach's alpha $=0.84$ ).

Online and offline service experience was included as a control variable to account for citizens' recent experience with government services using a different channel. Frequency of visiting SMG websites was included to capture the degree of up-to-date information about SMG to which citizens were exposed. Obtaining political news through online media and obtaining political news through conventional media were included as dummy variables to control for the media's effects on citizens' perception of transparency in government.

It is likely that respondents' socioeconomic status (e.g., age and income) also affects their adoption of new technology, such as in active eparticipation. To control for these effects, we included age, measured on a continuous scale, as a control variable. Although education is likely to covary with income, we included education to control for its possible effects on perceptions of transparency in government. Education was measured on an interval scale, with codings of 1 through 5 for respondents with a high school diploma, enrolled in a bachelor's degree program, possessing a bachelor's degree, enrolled in a master's degree program, and holding a master's degree, respectively. Likewise, income was represented by households' monthly income, with an interval scale ranging from more than $\$ 5,000$ (6) to less than $\$ 1,667$ (1).

\section{Results}

We used the robust regression analysis technique because we found wide variations in the measurement of citizen participation, which can create a heteroskedasticity problem. As an alternative to ordinary least squares, robust regression analysis is often used when data contain outliers or particularly influential observations.

To test the research hypotheses, four models of perceived transparency in government were analyzed. Model 1, constructed to test Hypothesis 1, included the citizen participation variable and all control variables. As a key independent variable, citizen participation captures use of any type of public participation programs regardless of the channel. Model 2 was designed to test Hypothesis 2; it consists of citizens' online participation as a key independent variable, along with all control variables. Model 3 tested whether citizens' participation during the different policymaking phases (policy agenda setting, implementation, and evaluation) was associated with perceived transparency. Model 4 was constructed to further analyze the extent to which citizens' online and offline participation at different policymaking stages was related to transparency.

Table 3 reveals the robust regression estimation results of the four models. Contrary to our expectation that citizen participation should be positively associated with transparency in government, Model 1 shows that Hypothesis 1 was not supported by the data. In other words, the relationship between respondents' engagement in citizen participation programs provided by SMG and their perception of enhanced transparency in SMG was not statistically significant.

Model 2 shows that Hypothesis 2 was also not supported by the data. In fact, the study results indicated that online participation was marginally significant and negatively associated with transparency $(\beta=-0.26, \mathrm{p}<0.1)$. Respondents who engaged in online participation programs did not indicate a more favorable assessment of transparency in SMG. In other words, respondents who engaged in offline participation programs reported a more positive perception toward transparency in SMG than those participating online.

The results of Model 3 demonstrate that respondents' participation in citizen programs designed to engage citizens during policy agenda setting was significantly and positively associated with their perception of transparency 
in SMG $(\beta=0.30, \mathrm{p}<0.05)$. Model 4 appears to reinforce the results of Models 2 and 3, indicating that respondents who experienced offline participation during policy agenda setting had a more positive assessment of transparency in $\mathrm{SMG}(\beta=0.38, \mathrm{p}<0.01)$.

Among the control variables, perceptions of government's efforts to engage citizens, offline service experience, and use of SMG websites were found to be factors related to transparency. Again contrary to our expectation, the use of SMG websites was negatively related to perception of transparency. The effects of the control variables were consistent across all models.

Table 3. Citizen Participation, Channel, Policymaking Process, and Transparency

\begin{tabular}{|c|c|c|c|c|c|c|c|c|}
\hline \multirow[b]{2}{*}{ Independent Variables } & \multicolumn{2}{|c|}{ Model 1} & \multicolumn{2}{|c|}{ Model 2} & \multicolumn{2}{|c|}{ Model 3} & \multicolumn{2}{|c|}{ Model 4} \\
\hline & Beta & S.E & Beta & S.E & Beta & S.E & & \\
\hline Citizen participation & -.03 & .10 & & & & & & \\
\hline Online participation & & & $-.26^{\star}$ & .14 & & & & \\
\hline $\begin{array}{l}\text { Citizen participation during policy agenda } \\
\text { setting phase }\end{array}$ & & & & & $.30 * \star$ & .12 & & \\
\hline $\begin{array}{l}\text { Citizen participation during policy } \\
\text { implementation phase }\end{array}$ & & & & & .02 & .07 & & \\
\hline $\begin{array}{l}\text { Citizen participation during policy } \\
\text { evaluation phase }\end{array}$ & & & & & -.10 & .15 & & \\
\hline $\begin{array}{l}\text { Offline participation during policy agenda } \\
\text { setting phase }\end{array}$ & & & & & & & $.38^{* * *}$ & .14 \\
\hline $\begin{array}{l}\text { Offline participation during policy } \\
\text { implementation phase }\end{array}$ & & & & & & & .01 & .17 \\
\hline $\begin{array}{l}\text { Offline participation during policy } \\
\text { evaluation phase }\end{array}$ & & & & & & & .02 & .07 \\
\hline $\begin{array}{l}\text { Online participation during policy agenda } \\
\text { setting phase }\end{array}$ & & & & & & & .10 & .19 \\
\hline $\begin{array}{l}\text { Online participation during policy } \\
\text { implementation phase }\end{array}$ & & & & & & & -.32 & .23 \\
\hline Control variables & & & & & & & & \\
\hline $\begin{array}{l}\text { Perception of government's efforts to } \\
\text { engage citizens }\end{array}$ & $.52^{* * *}$ & .02 & $.52^{\star \star \star}$ & .02 & $.52^{\star \star \star}$ & .02 & $.52^{\star \star \star}$ & .02 \\
\hline Offline service experience & $.17^{\star \star}$ & .08 & $.19 * *$ & .08 & $.16^{\star \star}$ & .08 & $.16^{\star *}$ & .08 \\
\hline Online service experience & .08 & .10 & .09 & .10 & .08 & .10 & .09 & .10 \\
\hline Frequency of visiting SMG websites & $-.07^{*}$ & .04 & $-.06^{*}$ & .04 & $-.08 * *$ & .04 & $-.09 * *$ & .04 \\
\hline Political news through online media & -.01 & .02 & -.00 & .02 & -.01 & .02 & -.00 & .02 \\
\hline Political news through conventional media & .03 & .03 & .04 & .03 & .03 & .03 & .03 & .03 \\
\hline Gender $($ male $=1)$ & -.04 & .07 & -.04 & .07 & -.05 & .07 & -.05 & .07 \\
\hline Age & .00 & .00 & .00 & .00 & .00 & .00 & .00 & .00 \\
\hline Education & .04 & .04 & .04 & .04 & .04 & .04 & .04 & .04 \\
\hline Income & .02 & .04 & .02 & .04 & .03 & .04 & .02 & .04 \\
\hline $\mathrm{N}$ & 98 & & & & 98 & & & \\
\hline$R^{2}$ & .40 & & & & .4 & & & \\
\hline
\end{tabular}

${ }^{*} \mathrm{p}<.10 ;{ }^{* *} \mathrm{p}<.05 ;{ }^{* * *} \mathrm{p}<.01$ 


\section{Discussion and Future Research}

The study results indicate that citizens are more likely to perceive enhanced transparency in local government when they participate in offline programs. This finding is consistent with conventional citizen participation literature that implicitly and explicitly emphasizes the potential role of citizens' participation in offline settings in enhancing transparency $[2,6,25,34,38,39$, 45, 52]. For instance, Yang and Holzer [52] address the fact that participation introduces citizen monitoring, which increases the likelihood of catching deception and ensures government's commitment to openness and honesty.

Meanwhile, the study findings imply that citizens' participation in online programs is somewhat limited in enhancing their perception of transparency in local government. One possible explanation of this result is related to the nature of online participation technologies. Online participation gives citizens more convenient access to information that facilitates their participation and better interactivity with government. However, by its nature, online participation is limited in enabling citizens to physically observe how government officials deal with citizen input and make decisions.

Another possible explanation for this finding could be the lesser maturity of online participation tools. Online participation is a relatively new channel for both citizens and government, and thus it is probably still too early for users to take full advantage of its capabilities in facilitating citizen participation and exchanges of ideas. Survey evidence on citizens' use of eparticipation in the states demonstrates that citizens were most likely to use e-participation for management activities and much less likely to use the Internet for more advanced consultative and participatory activities [37]. Meanwhile, on the government side, the literature on citizen participation shows that local governments still underutilize the possibilities of active online participation programs [37, 41, 43, 51]. Based on a national survey of 428 U.S. local governments, Yang and Callahan [51] found that citizen input is not frequently sought in decision making or in functional areas that are managerial or technical or involve issues of confidentiality. Royo, Yetano, and Acerete [41] found similarly that most local governments in Germany and Spain use citizen participation only to increase the level of perceived legitimacy or to comply minimally with legal requirements, without really taking advantage of citizen participation to enhance decision-making processes.

In order to enhance our understanding of the theoretical and practical implications of the association between citizen participation and transparency, scholars should pay more attention to when and how different types of participation programs facilitate citizens' assessment of transparency in local government. For example, measurements of citizen participation can be distinguished into two dimensions: consultation and active participation [31]. Consultation seeks out citizen participants' involvement in the decision process; in other words, "government asks for and receives citizens' feedback on policy-making" [31, p. 15]. Active participation highlights "citizens' engagement in decisionmaking and policy-making" [31, p. 17].

Through active participation, citizens could initiate two-way interactions with government by suggesting policy and program ideas, giving feedback on existing government programs, and sharing ideas with other participants. As a result of engaging in active participation programs, citizens may assume a greater monitoring role and perceive stronger ownership and empowerment with regard to public administration. In this way, citizens' experiences in active participation programs could become positively associated with their assessments of transparency in local government. Accordingly, future research should analyze how citizens' experiences with active participation facilitate their assessment of transparency in local government compared to their experiences in consultation or information access.

\section{Conclusion}

Using the 2009 Citizen Survey data on the Seoul Metropolitan Government, this study finds that citizens' engagement in offline participation programs is directly associated with their assessment of government transparency. It also finds that citizens who engage in offline participation programs during the policy agenda setting stage give higher assessments of transparency in local government. This exploratory study contributes to the transparency literature by uncovering the role of citizen participation channels and timing in influencing citizens' assessment of transparency in government. However, its external validity is limited, since the study was conducted only in one city in South Korea, so the findings must be applied with caution to other research settings. 


\section{References}

[1] Arnstein, Sherry R. A Ladder of Citizen Participation. Journal of the American Planning Association, 35, 4 (1969), 216-224.

[2] Bertot, John C., Paul T. Jaeger, and Justin M. Grimes. Using ICTs to create a culture of transparency: E-government and social media as openness and anti-corruption tools for societies. Government Information Quarterly, 27 (2010), 264 271.

[3] Bimber, Bruce. The Internet and citizen communication with government: does the medium matter?. Political Communication, 16 (1999), 409-428. [4] Blackburn, Walton J., and Willa M. Bruce. 1995. Mediating Environmental Conflicts: Theory and Practice. Westport, CT: Quorum Books.

[5] Borgea, Rosa, Clelia Colombob, and Yanina Welpc. Online and Offline Participation at the Local Level: A quantitative analysis of the Catalan municipalities. Information, Communication \& Society, 12, 6 (2009), 899-928.

[6] Box, Richard. 2007. Citizen Governance: Leading American Communities into the 21st Century. Thousand Oaks, CA: Sage Publication.

[7] Brewer, Gene A. Building social capital: Civic attitudes and behavior of public servants, Journal of Public Administration Research and Theory, 13, 1 (2003), 5-26.

[8] Chadwick, Andrew. Bring E-Democracy Back In: Why It Matters for Future Research on E-Governance. Social Science Computer Review, 21, 4 (2003), 44355.

[9] Cheema, G. Shabbir. Strengthening the integrity of government: Combating corruption through accountability and transparency, In Reinventing government for the twenty-first century: State capacity in a globalizing society, Dennis A. Rondinelli \& G. Shabbir Cheema, 99-120, Bloomfield, CT: Kumarian Press, 2003.

[10] Citrin, Jack and Christopher Muste. Trust in government, In Measures of Political Attitudes, John P. Robinson, Phillip R. Shaver \& Lawrence S, 462-532, Wrightsman, New York: Academic Press, 1999.

[11] Coleman, Renita, Paul Lieber, Andrew L. Mendelson, and David D. Kurpius. Public Life and the Internet: If You Build a Better Website, Will Citizens Become Engaged?. New Media \& Society, 10, 2 (2008), 179-202.

[12] Cooper, Terry L., Thomas A. Bryer, and Jack W. Meek. Citizen-Centered Collaborative Public Management. Public Administration Review. 66, 1 (2006), 76-88.

[13] Fountain, Jane. E. 2001. Building the virtual state: Information technology and institutional change. Washington, D.C: Brookings Institution Press.

[14] Fung, Archon Varieties of Participation in Complex Governance. Public Administration Review, 66, 1 (2006), 66-75.

[15] Hambleton, Robin, and Jill Simone Gross. 2007. Governing Cities in a Global Era: Urban Innovation, Competition, and Democratic Reform. New York, NY: Palgrave Macmillan.
[16] Irvin, Renee A. and John Stansbury. Citizen Participation in Decision Making: Is it Worth the Effort?. Public Administration Review, 64, 1 (2004), 55-65.

[17] Justice, Jonathan B., James Melitzki and Daniel L. Smith. E-Government as an Instrument of Fiscal Accountability and Responsiveness: Do the Best Practitioners Employ the Best Practices?. American Review of Public Administration, 36 (2005), 301.

[18] Kim, Pan Suk. A Daunting Task in Asia. Author. Public Management Review, 10, 4 (2008), pp. 527-537. [19] Kim, Soonhee. 2009. Management Strategy for Local Governments to Strengthen Transparency in Local Governance. Seoul: United Nations Project Office on Governance.

[20] Kim, Soonhee. Public Trust in Government in Japan and South Korea: Does the Rise of Critical Citizens Matter?. Public Administration Review, 70, 5 (2010), 801-810.

[21] Kim, Soonhee and Jooho Lee. E-Participation, Transparency, and Trust in Local Government. Public Administration Review, 72, 6 (2012), 819-828.

[22] Kim, Minjeong, Jung-Hwan Kim, and Sharron J. Lennon. Online Service Attributes Available on Apparel Retail Web Sites: An E-S-Qual Approach. Managing Service Quality, 16, 1 (2006), 51-77.

[23] King, Cheryl S., Kathryn M. Feltey, and Bridget O. Susel. The Question of Participation: Toward Authentic Public Participation in Public Administration. Public Administration Review, 58, 4 (1998), 317-327.

[24] Kraemer, Kenneth L. and Jason Dedrick, J. Computing and public organizations. Journal of Public Administration Research and Theory, 7, 1 (1997), 89-112.

[25] Kweit, Mary G. and Robert W. Kweit. Participation, Perception of Participation, and Citizen Support. American Politics Research, 35, 3 (2007), 407-425.

[26] Macintosh, Ann and Angus Whyte. Towards an Evaluation Framework for eParticipation. Transforming Government: People, Process \& Policy, 2, 1 (2008), 16-30.

[27] Nelson, Nici and Susan Wright. 1995. Power and Participatory Development: Theory and Practice. London: Intermediate Technology Publications.

[28] Norris, Pippa. 1999. Critical Citizens: Global Support for Democratic Government. New York: Oxford University Press.

[29] O'Leary, Rosemary and Lisa Blomgren Bingham. 2008. The Collaborative Public Manager. Washington, DC: Georgetown University Press.

[30] O'Leary, Rosemary, David M. Van Slyke, and Soonhee Kim, eds. 2010. The Future of Public Administration Around the World: The Minnowbrook Perspective. Washington, DC: Georgetown University Press.

[31] Organization for Economic Co-operation and Development. 2001. Citizens as Partners: Information, Consultation and Public Participation in PolicyMaking. Organization for Economic Co-operation and Development. 
[32] Organization for Economic Co-operation and Development. 2003. Checklist for E-Government Leaders. The Public Affairs Division, Public Affairs and Communications Directorate.

[33] Parasuraman, A., Valarie Zeithaml, and Arvind Malhotra. E-S-Qual: A Multiple-Item Scale for Assessing Electronic Service Quality. Journal of Service Research, 7, 3 (2005), 213-233.

[34] Phillips, Patricia, and Bernard Abey. Using the web to increase transparency and accountability. Government Finance Review, 23, 3 (2007), 32-38.

[35] Pope, Jeremy. Dimensions of Transparency in Governance. Paper presented at the 6th Global Forum on Reinventing Government, Seoul, Republic of Korea, May, (2005), 24-27.

[36] Putnam, Robert. Bowling alone: America's declining social capital. Journal of Democracy, 6, 1 (1995), 65-78.

[37] Reddick, Christopher G. Citizen Interaction and E-government: Evidence for the Managerial, Consultative, and Participatory Models. Transforming Government: People, Process and Policy, 5, 2 (2011), $167-184$.

[38] Robbins, Mark D., Bill Simonsen, and Barry Feldman. Citizens and Resource Allocation: Improving Decision Making with Interactive WebBased Citizen Participation. Public Administration Review, 68, 3 (2008), 564-575.

[39] Roberts, Nancy. Public Deliberation in an Age of Direct Citizen Participation. American Review of Public Administration, 34, 4 (2004), 315-353.

[40] Rowe, Gene, \& Frewer, Lynn. J. A typology of public engagement mechanisms. Science Technology and Human values, 30, 2 (2005), 251-290.

[41] Royo, Sonia, Ana Yetano, and Basilio Acerete. Citizen Participation in German and Spanish Local Governments: A Comparative Study. International Journal of Public Administration, 34, 3 (2011), 139150.

[42] Sabatier, Paul A. An Advocacy Coalition Framework of Policy Changes and the Role of PolicyOriented Learning Therein. Policy Sciences 21, 2/3 (1988), 129-168.

[43] Scott, James K. 'E' the People: Do U.S. Municipal Government Web Sites Support Public Involvement?. Public Administration Review, 66, 3 (2006), 341-353.

[44] Thomas, John Clayton. Public Involvement and Governmental Effectiveness: A Decision-Making Model for Public Managers. Administration \& Society 24, 4 (1993), 444-69.

[45] Tolbert, Caroline, and Ramona McNeal. Unraveling the Effects of the Internet on Political Participation. Political Research Quarterly 56, (2003), 175-185.

[46] Transparency International and the United Nations Human Settlements Programme. 2004. Tools for Support Transparency in Local Governance: Urban Governance Toolkit Series. Germany: Transparency International.

[47] Verba, Sidney, Kay Lehman Schlozman, and Henry Brady. 1995. Voice and Equality: Civic
Voluntarism in American Politics. London: Harvard University Press.

[48] Weeks, Edward C. The Practice of Deliberative Democracy: Results from Four Large-Scale Trials. Public Administration Review, 60, 4 (2000), 360-371. [49] Welch, Eric W., Charles C. Hinnant, M. Jae Moon. Linking Citizen Satisfaction with EGovernment and Trust in Government. Journal of Public Administration Research and Theory, 15, 3 (2005), 371-391.

[50] West, Darrell M. E-government and the Transformation of Service Delivery and Citizen Attitudes. Public Administration Review, 64, 1 (2004), 15-27.

[51] Yang, Kaifeng, and Kathe Callahan. Assessing Citizen Involvement Efforts by Local Governments. Public Performance \& Management Review, 29, 2 (2005), 191-216.

[52] Yang, Kaifeng, and Marc Holzer. The Performance-Trust Link: Implications for Performance Measurement. Public Administration Review, 66, 1 (2006), 114-26.

[53] Yankelovich, Daniel. 1991. Coming to Public Judgment. Syracuse: Syracuse University Press.

\section{Appendix. Survey Items}

Transparency in government (2 items, 5 point-Likert scale):

SMG's civil application processes have been more transparent.

SMG's decision making processes have been more transparent.

Citizens' use of participation programs (25 items)

Have you participated in the participation programs administered by SMG in the past three years? Please check all that apply.

Perceived government's efforts to engage citizens (3 items, 5 point-Likert scale)

SMG has promoted two-way communication with the public.

SMG has provided the citizens of Seoul with diverse opportunities to participate in the rule making process. SMG has provided the citizens of Seoul with an equal opportunity to participate in the rule making process. 